\title{
Numerical evaluation of turbulent flow in a circular conduit along a side weir
}

\author{
Meysam Bagherifar ${ }^{1} \cdot$ Ayoub Emdadi $^{2} \cdot$ Hamed Azimi $^{3} \cdot$ Babak Sanahmadi $^{4} \cdot$ Saeid Shabanlou $^{5}$
}

Received: 25 July 2019 / Accepted: 10 December 2019 / Published online: 20 December 2019

(C) The Author(s) 2019

\begin{abstract}
Side weir is used as a slot in the side wall of the main channel to direct excess water that is above the weir crest. Such structures are used in control of flow level in irrigation, drainage networks and urban sewage disposal systems. Furthermore, circular channels are pretty important because considerable length of sewage disposal and transmission pipeline system is made of circular channels. In this study, changes inflow free surface, turbulence and flow field passing through a circular channel along a side weir are simulated. This means that for modeling the variations in flow free surface and the flow field turbulence, the volume-of-fluid scheme and RNG $k-\varepsilon$ turbulence model are used, respectively. In order to validate the accuracy of the numerical model, the flow free surface changes along the side weir, the discharge coefficient of side weir, discharge of side weir, Froude number at upstream of the side weir and specific energy are compared with the experimental measurements. Comparison of simulation results with the experimental measurements shows high accuracy of CFD model. In other words, the root-mean-square error percent and the mean absolute error for flow free surface are, respectively, obtained to be $0.554 \%$ and $0.547 \%$. Moreover, average difference between the specific energy at upstream and downstream of the side weir is calculated about $2.1 \%$. The main purpose of this simulation is gaining an understanding of behavior of the passing flow through circular channels with side weir for subcritical flow regime.
\end{abstract}

Keywords Circular channel $\cdot$ Side weir $\cdot$ Numerical simulation $\cdot$ VOF scheme $\cdot$ RNG $k-\varepsilon$ model

\section{List of symbols}

$A_{x}, A_{y}, A_{z} \quad$ Fractional areas open to flow (-)

$A \quad$ Cross-sectional area $\left(\mathrm{m}^{2}\right)$

$C_{\mathrm{de}} \quad$ Experimental discharge coefficient (-)

$C_{\mathrm{dn}} \quad$ Numerical discharge coefficient (-)

$C_{u} \quad$ Constant coefficient (-)

$D \quad$ Channel diameter (m)

$E_{1} \quad$ Specific energy at section 1 in the main channel (m)

Saeid Shabanlou

Saeid.shabanlou@gmail.com

1 Department of Civil Engineering, Shushtar Branch, Islamic Azad University, Shushtar, Iran

2 Department of Civil Engineering, Hamadan Branch, Islamic Azad University, Hamadan, Iran

3 Department of Civil Engineering, Water and Wastewater Research Center, Razi University, Kermanshah, Iran

4 Department of Water Engineering, Faculty of Agriculture, Bu-Ali Sina University, Hamadan 6517838695, Iran

5 Department of Water Engineering, Kermanshah Branch, Islamic Azad University, Kermanshah, Iran
$E_{2} \quad$ Specific energy at section 2 in the main channel (m)

$F \quad$ Fluid volume fraction in a cell (-)

$F_{1} \quad$ Froude number at beginning of side weir on axis of main channel (-)

$f_{x}, f_{y}, f_{z} \quad$ Viscous accelerations (-)

$G_{x}, G_{y}, G_{z}$ Body accelerations (-)

$g \quad$ Acceleration gravity $\left(\mathrm{m} / \mathrm{s}^{2}\right)$

$k_{\mathrm{t}} \quad$ Turbulence kinetic energy $\left(\mathrm{m}^{2} / \mathrm{s}^{2}\right)$

$L \quad$ Side weir length (m)

$P \quad$ Side weir height $(\mathrm{m})$

$p \quad$ Pressure $\left(\mathrm{N} / \mathrm{m}^{2}\right)$

$Q_{1} \quad$ Discharge at section 1 in the main channel $\left(\mathrm{m}^{3} / \mathrm{s}\right)$

$Q_{\text {w }} \quad$ Discharge over the side weir $\left(\mathrm{m}^{3} / \mathrm{s}\right)$

$q \quad$ Discharge per unit length of the side weir $\left(\mathrm{m}^{2} / \mathrm{s}\right)$

$R_{\mathrm{SOR}} \quad$ Mass source (-)

$T_{\text {len }} \quad$ Turbulent length scale (m)

$t \quad$ Time (s)

$u, v, w \quad$ Velocity components $(\mathrm{m} / \mathrm{s})$

$V_{\mathrm{F}} \quad$ Fractional volume open to flow (-) 


\begin{tabular}{|c|c|}
\hline$x, y, z$ & Cartesian coordinate directions (m) \\
\hline$x$ & Distance from upstream of the weir $(\mathrm{m})$ \\
\hline$z$ & Depth of the flow (m) \\
\hline$z_{1}$ & $\begin{array}{l}\text { Depth of the flow at section } 1 \text { in the main } \\
\text { channel (m) }\end{array}$ \\
\hline$z_{2}$ & $\begin{array}{l}\text { Depth of the flow at section } 2 \text { in the main } \\
\text { channel }(m)\end{array}$ \\
\hline$\alpha$ & Velocity distribution coefficient (-) \\
\hline$\varepsilon_{\mathrm{t}}$ & Turbulence dissipation rate $\left(\mathrm{m}^{2} / \mathrm{s}^{3}\right)$ \\
\hline & Turbulent kinematic viscosity $\left(\mathrm{m}^{2} / \mathrm{s}\right)$ \\
\hline & Fluid density $\left(\mathrm{kg} / \mathrm{m}^{3}\right)$ \\
\hline & Angle of spilling jet $\left(^{\circ}\right)$ \\
\hline
\end{tabular}

\section{Introduction}

A side weir is a hydraulic structure that is installed on the side wall of main channels to control the flow elevation. Flow passing over the side weirs is considered as spatially varied flow (SVF) with decreasing discharge. Side weirs are widely used in hydraulic and environmental projects: for example, irrigation and drainage systems, urban sewage disposal networks and flood control projects. Many experimental and analytical studies have been conducted on flow pattern within rectangular channels along the side weir: for instance, Borghei et al. (1999), Yüksel (2004), Venutelli (2008), Emiroglu et al. (2011), Bagheri and Heidarpour (2012) and Novak et al. (Novak et al. 2013).

Channels with triangular and trapezoidal cross section are widely used in drainage and irrigation networks. For triangular channels, Uyumaz (1992) using finite difference method and specific energy principles has provided an analytical solution that predicts the flow free surface and discharge of side weir. Vatankhah (2012a) using the specific energy principle has provided an analytical solution to predict the flow free surface along the side weir. Also, Azimi and Shabanlou $(2015,2016)$ simulated flow field within triangular canals along the side weirs in subcritical and supercritical flow regimes. In association with passing flow through trapezoidal channels, Cheong (1991) and Vatankhah (2012b) have conducted experimental and numerical studies. Additionally, Azimi et al. (2017a, b, 2019) predicted discharge coefficient of side weirs by using some artificial intelligence techniques.

For the U-shaped channel along the side weir, Uyumaz (1997) presented an analytical study to predict the flow free surface and discharge of the side weir in supercritical and subcritical flow conditions. Vatankhah (2012c) introduced a semi-analytical method for predicting the flow free surface in U-shaped channel along a side weir using the specific energy principles and integrating method. Also, Vatankhah (2013) using incomplete elliptic integrating method provided a semi-analytical solution for solving the governing equation of spatially varied flow for parabolic channels along a side weir. In addition, Azimi and Shabanlou $(2018,2019)$ modeled turbulent flow and free surface in the U-shaped canals along the side weirs in both subcritical and supercritical flow regimes.

In practice, channel with circular cross section are widely used in sewage disposal networks. Allen (1957) conducted some experiments on flow within circular channels along the side weir. Uyumaz and Muslu (1985) conducted an experimental study on flow in circular channels with a side weir for subcritical and supercritical flow regimes. Oliveto et al. (2001) investigated characteristics of the passing flow over a side weir located on a circular channel. In their laboratory model, the flow along the side weir was supercritical. Ramamurthy et al. (1995) using the flow two-dimensional theory provided a relationship for calculating the discharge coefficient of side weir located on a circular channel. Vatankhah (2012d) presented a solution for predicting the flow free surface along the side weir located on a circular channel using the specific energy principles and incomplete elliptic integrals method.

Recently, numerical modeling is used as a powerful and reliable tool in simulating of flow in hydraulic structures. Mahmodinia et al. (2012) using Fluent software, RSM turbulence model and volume-of-fluid (VOF) method simulated the flow pattern in rectangular channels along the side weir. Aydin (2012) using VOF method simulated the changes in flow free surface along the triangular labyrinth side weir located on a rectangular channel. Aydin and Emiroglu (2013) predicted the discharge capacity of labyrinth side weirs located on rectangular channel using Fluent-ANSYS model. Also, the characteristics of flow field along labyrinth side weir were numerically investigated. Azimi et al. (2014) modeled the velocity field and variations in flow free surface along the rectangular side weir within circular channels for supercritical flow conditions. Azimi et al. (2015) introduced an equation for predicting the discharge capacity of the rectangular side weirs on circular channels using numerical simulation. Flow field in triangular channel along the side weir for subcritical flow regime was numerically simulated by Azimi and Shabanlou (2015). Also, Aydin and Emiroglu (2016) analyzed the flow over two-cycle trapezoidal labyrinth side weir numerically using Fluent-ANSYS software.

Numerical simulations have widely been used in modeling engineering phenomena, with the number of such investigations increasing constantly. Also, according to the literature, despite the importance of awareness about flow field within circular channels along the side weir, very few experimental, analytical and numerical studies have been done on this issue.

The main aim of this CFD simulation is obtaining proper understanding of the flow field hydraulic behavior within circular channels along the side weir in subcritical flow regimes. Therefore, in this study the characteristics of flow 
field within circular channels along a side weir in subcritical flow regime are simulated using FLOW-3D software. In this numerical analysis, variations in the flow free surface and the flow field turbulence are simulated using the volumeof-fluid (VOF) scheme and the RNG $k-\varepsilon$ turbulence model, respectively.

\section{Materials and methods}

\section{Governing equations}

In this study, to solve the flow field of a noncompressible fluid in Cartesian coordinate system, the continuity equation and Reynolds-averaged Navier-Stokes equations are used as follows (Azimi and Shabanlou 2015):

$V_{\mathrm{F}} \frac{\partial \rho}{\partial t}+\frac{\partial\left(\rho u A_{x}\right)}{\partial x}+\frac{\partial\left(\rho v A_{y}\right)}{\partial y}+\frac{\partial\left(\rho w A_{z}\right)}{\partial z}=R_{\mathrm{SOR}}$

$\frac{\partial u}{\partial t}+\frac{1}{V_{\mathrm{F}}}\left(u A_{x} \frac{\partial u}{\partial x}+v A_{y} \frac{\partial u}{\partial y}+w A_{z} \frac{\partial u}{\partial z}\right)=-\frac{1}{\rho} \frac{\partial p}{\partial x}+G_{x}+f_{x}$

$\frac{\partial v}{\partial t}+\frac{1}{V_{\mathrm{F}}}\left(u A_{x} \frac{\partial v}{\partial x}+v A_{y} \frac{\partial v}{\partial y}+w A_{z} \frac{\partial v}{\partial z}\right)=-\frac{1}{\rho} \frac{\partial p}{\partial y}+G_{y}+f_{y}$

$\frac{\partial w}{\partial t}+\frac{1}{V_{\mathrm{F}}}\left(u A_{x} \frac{\partial w}{\partial x}+v A_{y} \frac{\partial w}{\partial y}+w A_{z} \frac{\partial w}{\partial z}\right)=-\frac{1}{\rho} \frac{\partial p}{\partial z}+G_{z}+f_{z}$

where $(u, v, w),\left(A_{x}, A_{y}, A_{z}\right),\left(G_{x}, G_{y}, G_{z}\right)$ and $\left(f_{x}, f_{y}, f_{z}\right)$ are the velocity components, fractional area open to flow, gravitational forces and accelerations due to viscosity in $x$-, $y$ - and $z$-directions, respectively. Also $t, \rho, R_{\mathrm{SOR}}, p$ and $V_{\mathrm{F}}$ are time, density, term of the source, pressure and fractional volume open to flow, respectively. In this study, for simulation of flow turbulence, the $k-\varepsilon$ RNG turbulence model has been used. Also, the flow free surface changes have been modeled using volume-of-fluid (VOF) scheme. The VOF method is composed of three main components:

(a) The definition of the volume-of-fluid function,

(b) Solution of the VOF transport equation,

(c) Setting the boundary conditions at the free surface.

In VOF scheme to calculate the volume component, the following continuity equation is solved (Azimi and Shabanlou 2015):

$\frac{\partial F}{\partial t}+\frac{1}{V_{\mathrm{F}}}\left(\frac{\partial}{\partial x}\left(F u A_{x}\right)+\frac{\partial}{\partial y}\left(F v A_{y}\right)+\frac{\partial}{\partial z}\left(F w A_{z}\right)\right)=0.0$ where $F$ is the volume component of fluid in a specified computational cell. If $F=0$, the cell is empty, if $F=1$, the computational cell is filled with fluid, and if $0<F<1$, cell is composed of both phases of air and water.

\section{Boundary conditions}

The specified amounts of discharge and flow depth were used in the inlet boundary conditions. In the main channel outlet, the specified amounts of depth and pressure are used (the flow depth and pressure are equal to $0.1476 \mathrm{~m}$ and atmospheric pressure, respectively). In the location of the side weir, a tank is considered. The downstream of the tank is defined as the outlet boundary condition. All of the solid walls including side walls and the main channel bed are considered as the wall boundary condition. The entire upper surface of the air phase is considered as the symmetry boundary conditions.

\section{Experimental model}

In this numerical study, the results obtained from CFD analysis are compared with experimental data measured by Uyumaz and Muslu (1985). Laboratory tools used by Uyumaz and Muslu include a horizontal circular channel. The length and diameter of the main channel are considered to be $10.9 \mathrm{~m}$ and $0.25 \mathrm{~m}$, respectively. Also, the side weir is made of fiberglass panels, and its length and height are $0.5 \mathrm{~m}$ and $0.1 \mathrm{~m}$, respectively.

\section{Gridding of flow field}

In Table 1, the results of the gridding independent used in the numerical modeling for the flow free surface are shown. As shown in Table 1, the difference between the gridding 4 and 5 results is negligible and gridding 4 is chosen for the computational field. To check the numerical model accuracy, the root-mean-square error percent (RMSE) and the mean absolute error (MAE) values are calculated using the following equations:

Table 1 Results of meshing independency

\begin{tabular}{llll}
\hline Meshing & Number of cells & RMSE (\%) & MAE (\%) \\
\hline 1 & 167,250 & 5.341 & 4.720 \\
2 & 514,880 & 3.410 & 2.953 \\
3 & 605,760 & 1.915 & 1.023 \\
4 & 813,130 & 0.554 & 0.547 \\
5 & 921,350 & 0.473 & 0.385 \\
\hline
\end{tabular}


RMSE $=100 \times \sqrt{\frac{1}{N} \sum_{i=1}^{N}\left(R_{\text {(measured) }}-R_{\text {(simulated) }}\right)^{2}}$

MAE $=\frac{100}{N} \sum_{i=1}^{N}\left|R_{\text {(measured) }}-R_{\text {(simulated) }}\right|$

To simulate the numerical model, the whole computational domain is gridded by a nonuniform mesh block consisting of rectangular elements (Fig. 1). The main circular channel is gridded by 186, 60 and 61 elements in directions $x, y$ and $z$, respectively, and the tank attached to the side weir is gridded by 62,35 and 61 elements in directions $x, y$ and $z$, respectively.

\section{Results and discussion}

\section{Validation}

In the laboratory model, discharge within circular channel at side weir upstream $\left(Q_{1}\right)$ and the flow depth at upstream and downstream of the side weir are considered as $0.017 \mathrm{~m}^{3} / \mathrm{s}$, $0.1368 \mathrm{~m}$ and $0.1476 \mathrm{~m}$, respectively. Flow regime in this model is subcritical flow. Therefore, the flow free surface depth increases at the end of the side weir upstream toward the end of the side weir downstream. In Fig. 2, the flow depths upon the main channel and along the side weir obtained by the numerical simulation are compared with the experimental results measured.

The RMSE and MAE values for the flow depth are calculated to be $0.544 \%$ and $0.547 \%$, respectively, which indicate acceptable accuracy of the numerical analysis in modeling flow free surface. In the laboratory model of Uyumaz and Muslu (1985), different values of the side weir discharge have been measured. In Fig. 3, the results of the numerical simulation for different discharges of side weir are compared with laboratory values. The RMSE and MAE values for discharges of the side weir are calculated to be $0.041 \%$ and

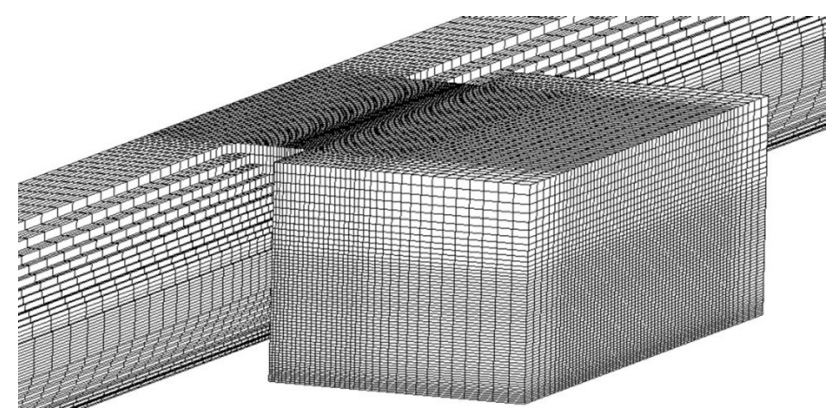

Fig. 1 Gridding of numerical model

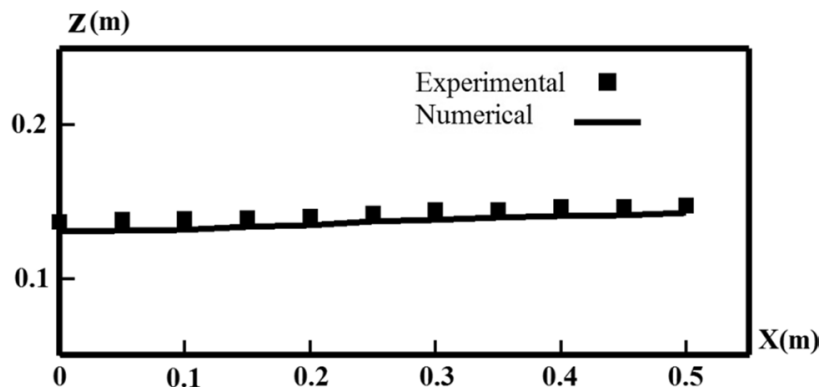

Fig. 2 Comparison of the flow longitudinal free surface profile variation between the numerical model and laboratory results

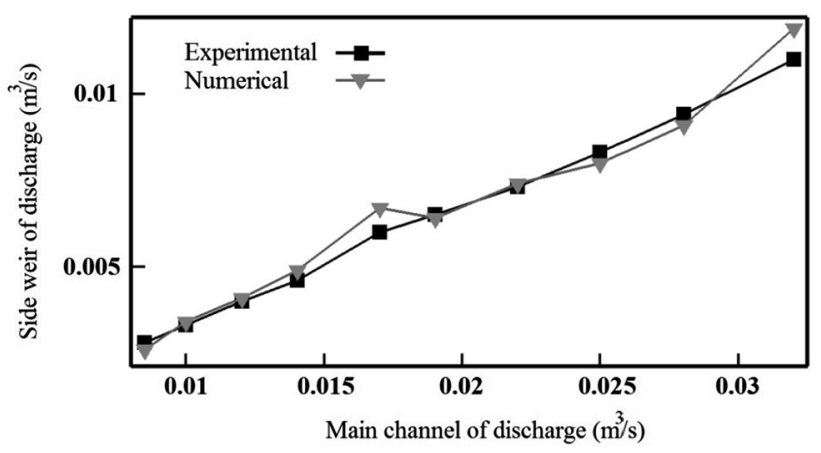

Fig. 3 Comparison of the simulated and laboratory results for the discharge of the side weir

$0.031 \%$, respectively, which indicate acceptable accuracy of the numerical model.

Discharge per length unit of a side weir that is located on a circular channel has been provided by Uyumaz and Muslu (1985) as follows:

$-\frac{\mathrm{d} Q_{\mathrm{w}}}{\mathrm{d} x}=q=C_{\mathrm{d}} \sqrt{2 g(z-P)}(z-P)$

where $Q_{\mathrm{w}}$ is the discharge of the side weir, $x$ is distance from upstream of the weir, $\mathrm{d} Q_{\mathrm{w}} / \mathrm{d} x$ or $q$ is the discharge per length unit of weir, $g$ is acceleration of gravity, $P$ is height of side weir and $z$ is flow depth. Thus, the side weir discharge coefficient is calculated as follows (Oliveto et al. 2001):

$C_{\mathrm{d}}=\left(\frac{Q_{\mathrm{w}}}{L \sqrt{2 g}(\mathrm{z}-P)^{\frac{3}{2}}}\right)$

where $L$ is length of side weir. Uyumaz and Muslu (1985) have provided empirical Eq. (10) to calculate the discharge coefficient of side weir located in a circular channel in the subcritical flow regime:

$$
\begin{aligned}
C_{\mathrm{d}}= & (0.21+0.094 \sqrt{1.75 L / D-1}) \\
& +(0.22-0.08 \sqrt{1.68 L / D-1}) \sqrt{1-F_{1}}
\end{aligned}
$$

لو مدينة الملأ عبدالعزيز KACST 
where $D$ is diameter of circular channel and $F_{1}$ is Froude number at upstream of side weir. Discharge coefficient of the side weir located on a circular channel for different relationships is shown in Table 2. Laboratory and numerical discharge coefficients are shown as $\left(C_{\mathrm{de}}\right)$ and $\left(C_{\mathrm{dn}}\right)$, respectively. To evaluate the numerical model accuracy in predicting discharge coefficient, the relative error percent was calculated by Eq. (11).

The numerical discharge coefficients were estimated to be 0.425 and 0.422 using Eqs. (9) and (10), respectively, while the experimental discharge coefficients were computed to be 0.384 and 0.419 using Eqs. (9) and (10), respectively. Therefore, the relative error percent values were calculated to be 10.7 and $0.72 \%$, respectively:

$\mathrm{REP}=100 \times\left|\frac{C_{\mathrm{de}}-C_{\mathrm{dn}}}{C_{\mathrm{de}}}\right|$.

In laboratory model, the specific energy has been measured as $0.1563 \mathrm{~m}$, while the simulated specific energy is equal to $0.1535 \mathrm{~m}$. Therefore, the relative error percent of the specific energy has been calculated to be $1.8 \%$, which indicates high accuracy of the numerical model in predicting the specific energy.

\section{Effects of Froude number}

In Fig. 4, variations in Froude number at the side weir's upstream $\left(F_{1}\right)$ against the dimensionless discharge within the main channel $\left(Q_{1} / Q_{\max }\right)$ are shown. As is shown by increasing the main channel discharge, Froude number increases. In Fig. 5, changes in the discharge coefficient $\left(C_{\mathrm{d}}\right)$ of the side weir against Froude number $\left(F_{1}\right)$ are shown. In this figure, the discharge coefficient is calculated by substituted Froude number in Eq. (10). The discharge coefficient of the side weir decreases by increasing the Froude number.

\section{Specific energy}

By assuming that the channel bed slope is insignificant, the specific energy along the side weir is constant and calculated as follows (Emiroglu et al. 2011):

Table 2 Comparison of experimental and numerical discharge coefficients

\begin{tabular}{llll}
\hline Equation nos. & $\left(C_{\mathrm{de}}\right)$ & $\left(C_{\mathrm{dn}}\right)$ & $(\mathrm{REP})(\%)$ \\
\hline$(9)$ & 0.384 & 0.425 & 10.7 \\
$(10)$ & 0.419 & 0.422 & 0.72 \\
\hline
\end{tabular}

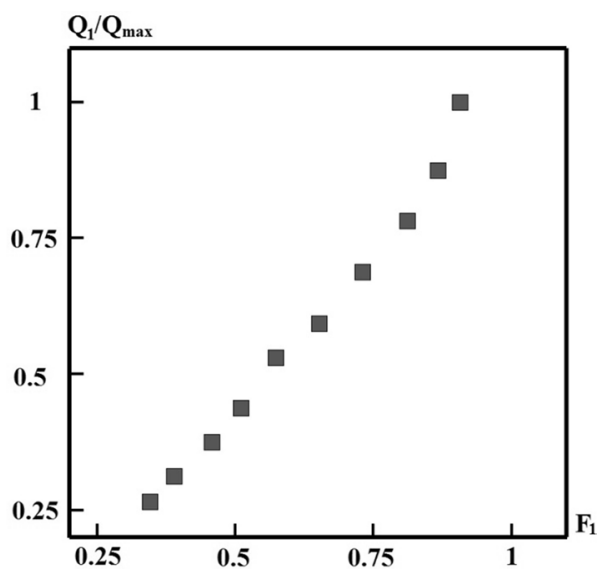

Fig. 4 Variations in Froude number against discharge within the main channel

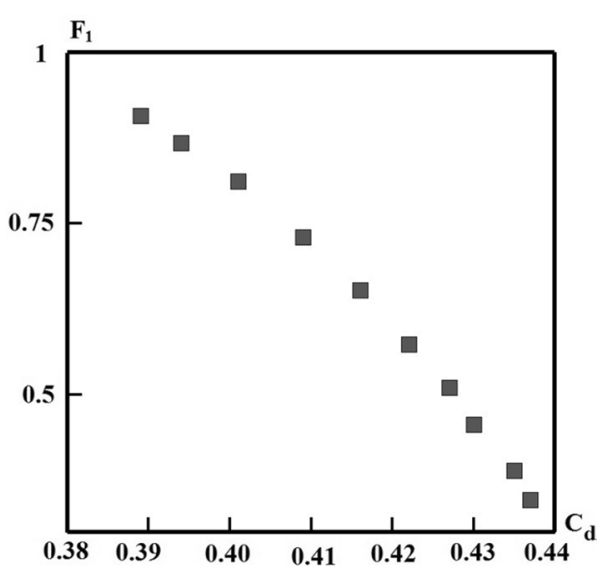

Fig. 5 Variations in discharge coefficient against Froude number

$E=z+\alpha\left(\frac{Q_{1}^{2}}{2 g A^{2}}\right)$

where $E$ is specific energy, $\alpha$ is velocity distribution coefficient, $Q_{1}$ is discharge within the main channel and $A$ is crosssectional area of flow. Constant specific energy assumption in solving governing equation for spatially varied flows is one of the fundamental principles. Hence, the specific energy in upstream of the side weir is compared with downstream of it. In Fig. 6, the specific energies at the upstream $\left(E_{1}\right)$ and downstream $\left(E_{2}\right)$ of the side weir are compared for various values of the discharge within the main channel. As shown, the specific energy along the side weir which is predicted by the numerical model is almost constant and the energy drop along the side weir is negligible. Average difference between the specific energy at upstream and downstream of the side weir is calculated to be about $2.1 \%$. Oliveto et al. (2001) and 


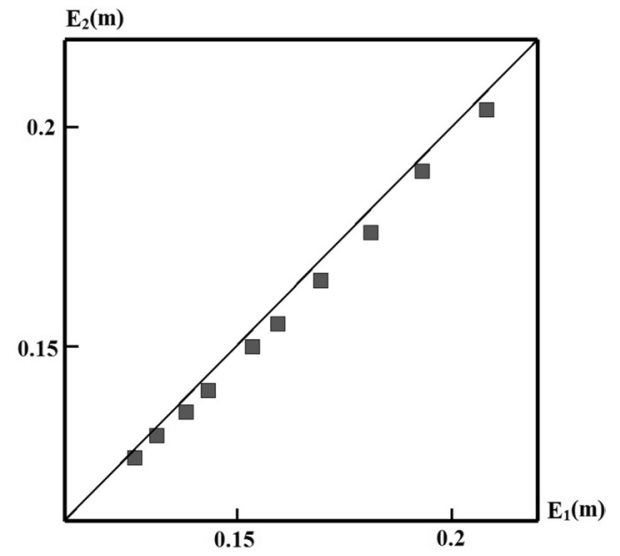

Fig. 6 Comparison of specific energy at upstream and downstream of the side weir for different discharges within the main channel

Borghei et al. (1999) in their laboratory results by comparing the specific energy at upstream and downstream of the side weir have calculated the difference between $E_{1}$ and $E_{2}$ to be equal to $5 \%$ and $3.7 \%$, respectively.

\section{Flow free surface along the side weir}

El-Khashab (1975), Emiroglu et al. (2010) and Aydin (2012) conducted some laboratory and numerical studies on behavior of the flow free surface within a rectangular channel along a side weir. In order to examine the variations in flow free surface along the side weir, profiles of simulated flow free surface are shown in Fig. 7. The variations in flow free surface before upstream and after downstream are negligible. As the flow approaches the side weir plane, due to effects of entrance, a free surface drop occurs at the side weir upstream. After this drop, the flow free surface increases rapidly and reaches its maximum at the downstream of the side weir. At the downstream of side weir, a surface jump occurred. Along the surface jump, kinetic energy increases and potential energy reduces. After the surface jump, the maximum flow free surface happens. This point introduces as stagnation point. The stagnation point has the lowest velocity and the highest water elevation.

\section{Surface velocities}

In Fig. 8, the contour of the longitudinal velocity $(u)$ on the main channel and in the vicinity of the free surface is shown. The maximum longitudinal velocity occurs at side weir's upstream. By advancing the flow along the side weir, the longitudinal velocity is reduced. The lowest longitudinal velocity $(u)$ occurs at the side weir upstream and near the inner bank.

In Fig. 9, the contour of lateral velocity $(v)$ is shown in the vicinity of the free surface. Due to the effects of the side weir, the maximum lateral velocity happened near the location of side weir. Also before and after the side weir, the lateral velocity is negligible.

\section{Angle of spilling jet}

The angle of spilling jet is known as a hydraulic feature of side weirs in the formation of diverted flow. Equation (13) was introduced by Bagheri and Heidarpour (2012) for estimation of angle of spilling jet (Azimi et al. 2017):

$\varphi=\operatorname{Arctan}\left(\frac{u}{v}\right)$

where $\varphi$ is the angle of spilling jet in the vicinity of the side weir in degrees and $u$ and $v$ are longitudinal and lateral velocity components, respectively. Changes in $\varphi$ along the side weir are shown in Fig. 10. At side weir upstream, the
Fig. 7 Simulated longitudinal profiles along the side weir

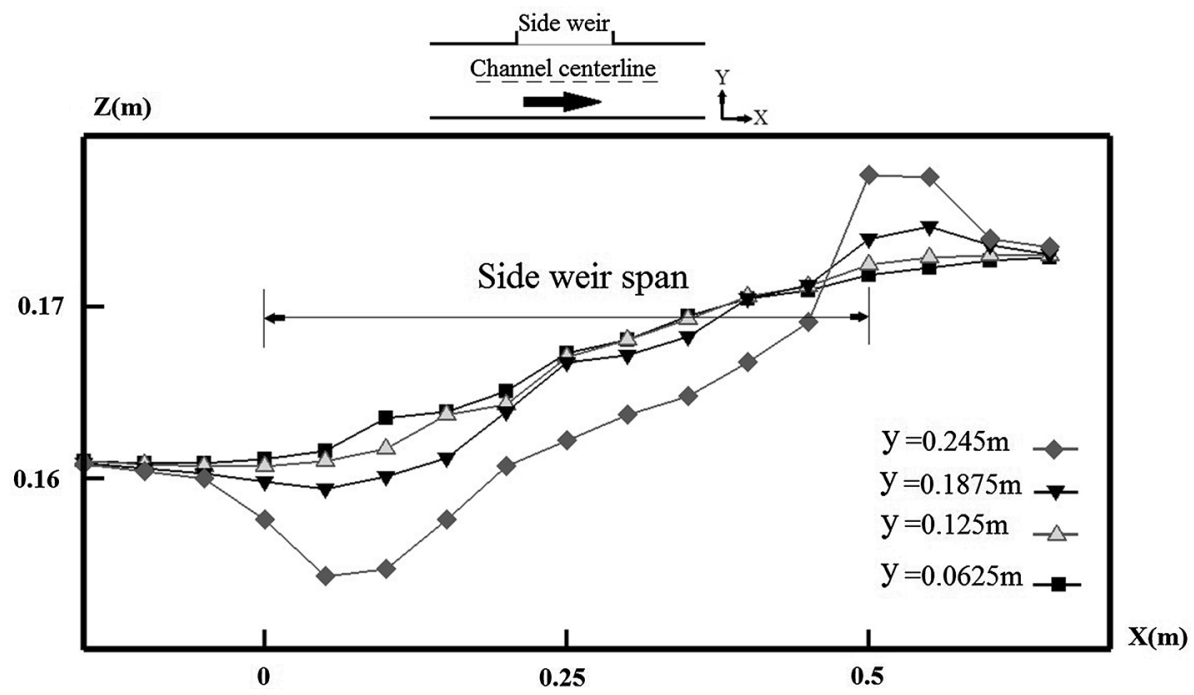


Fig. 8 Longitudinal velocity contours $(u)$ on the main channel simulated adjacent the upper level of the side weir crest

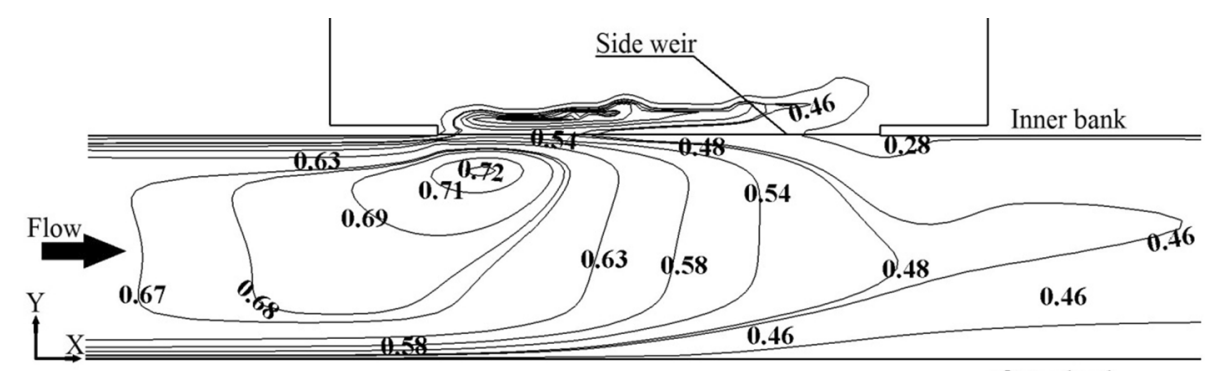

Outer bank

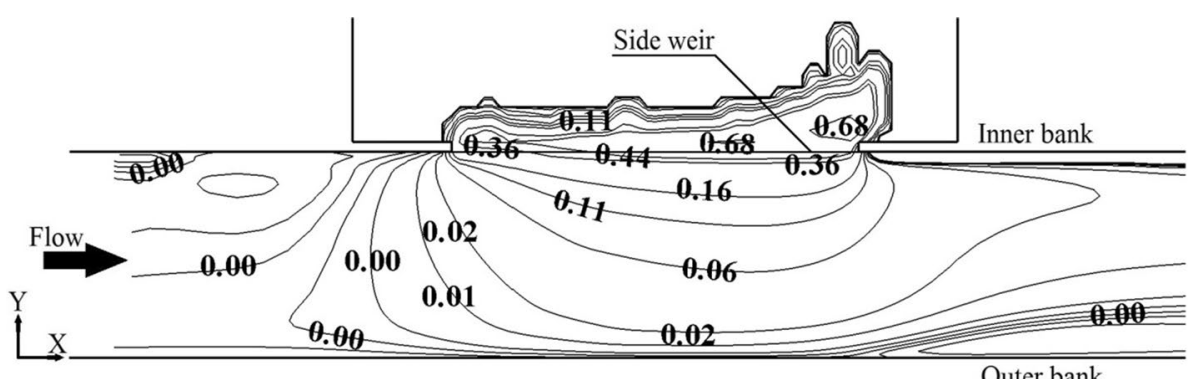

Outer bank
Fig. 9 Lateral velocity contours (u) on the main channel simulated adjacent to the upper level of the side weir crest

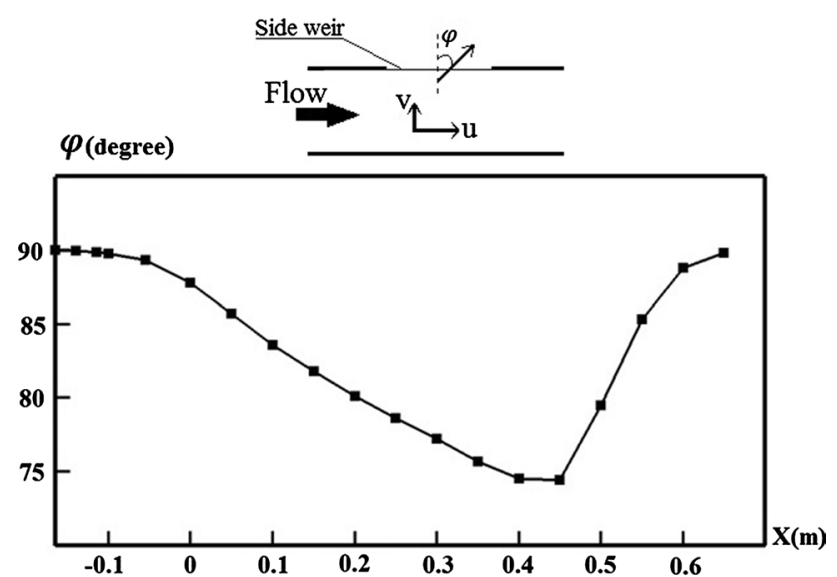

Fig. 10 Changes in angle of spilling jet in the vicinity of the side weir's crest

angle of spilling jet is measured to be almost $90^{\circ}$. On the other hand, the magnitude of lateral velocity is insignificant. At the downstream of side weir, the maximum angle of spilling jet occurred.

\section{Pressure distribution pattern}

In Fig. 11, the pressure distribution in the vicinity of the side weir is illustrated. As shown, by advancing toward

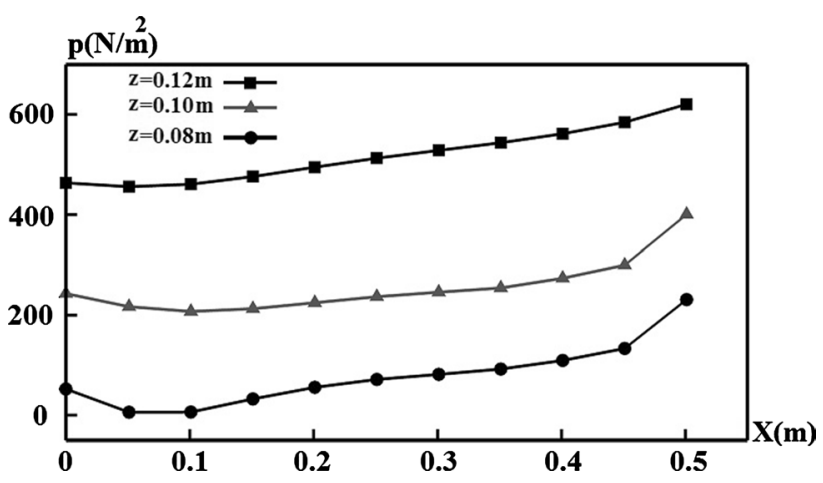

Fig. 11 Pressure distribution around the side weir for different levels

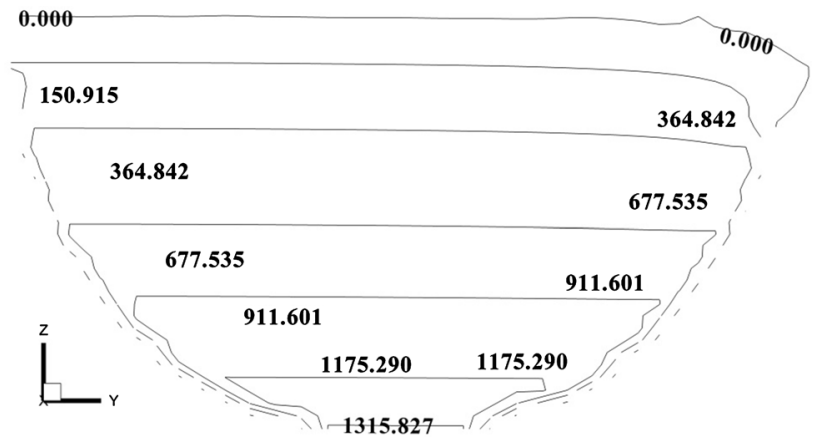

Fig. 12 Pressure contours in the circular channel at the middle of side weir 
Fig. 13 Surface pressure contours around the free surface in the circular channel

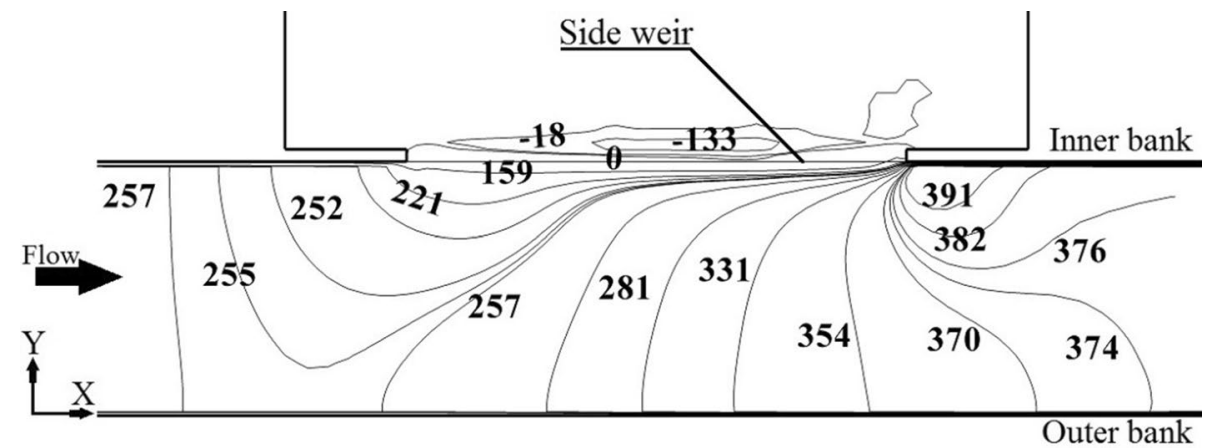

the side weir downstream, the pressure increases in all levels and the minimum pressure occurs at the side weir upstream. According to the numerical simulation results, by increasing the level along the side weir, the pressure amount increases as well.

The pressure contours in the circular channel at the middle of side weir are shown in Fig. 12. According to Fig. 12 by advancing from the channel bed to the free surface, the pressure amount decreases. Therefore, the maximum and minimum pressure occurs near the main channel bed and free surface, respectively.

The surface pressure contours in the vicinity of the side weir are shown in Fig. 13. As shown, the minimum and maximum pressures were predicted at the side weir upstream and its downstream, respectively. According to simulation result, by advancing toward the side weir downstream, the surface pressure in the circular channel increases.

\section{Conclusions}

In this study, the flow within a circular channel along a side weir was modeled using the FLOW-3D software and the RNG $k-\varepsilon$ turbulence model. Also, variations in the flow free surface were simulated by the VOF scheme. The CFD model predicted changes in the flow free surface with suitable accuracy. In this numerical study, the discharge coefficient of side weir is compared with the laboratory results by different equations and the discharge of the side weir is predicted with good accuracy. The side weir discharge coefficient reduces by increasing Froude number. The relative error percents for the Froude number and specific energy were computed as $6.2 \%$ and $1.8 \%$, respectively. According to numerical results, drop of the specific energy along the side weir was insignificant. Also, a surface jump occurred at the side weir downstream. After the surface jump, the stagnation point is observed. The maximum longitudinal velocity happened at beginning of the side weir. The angle of spilling jet before and after the side weir was simulated negligible. Also, the maximum and minimum pressure occurs near the channel bed and the flow free surface, respectively.

\section{Compliance with ethical standards}

Conflict of interest There is no conflict of interest between authors.

Open Access This article is licensed under a Creative Commons Attribution 4.0 International License, which permits use, sharing, adaptation, distribution and reproduction in any medium or format, as long as you give appropriate credit to the original author(s) and the source, provide a link to the Creative Commons licence, and indicate if changes were made. The images or other third party material in this article are included in the article's Creative Commons licence, unless indicated otherwise in a credit line to the material. If material is not included in the article's Creative Commons licence and your intended use is not permitted by statutory regulation or exceeds the permitted use, you will need to obtain permission directly from the copyright holder. To view a copy of this licence, visit http://creativecommons.org/licenses/by/4.0/.

\section{References}

Allen JW (1957) The discharge of water over side weirs in circular pipes. ICE Proc 6:270-287

Aydin MC (2012) CFD simulation of free-surface flow over triangular labyrinth side weir. Adv Eng Softw 45:159-166

Aydin MC, Emiroglu ME (2013) Determination of capacity of labyrinth side weir by CFD. Flow Meas Instrum 29:1-8

Aydin MC, Emiroglu ME (2016) Numerical analysis of subcritical flow over two-cycle trapezoidal labyrinth side weir. Flow Meas Instrum 48:20-28

Azimi H, Shabanlou S (2015) The flow pattern in triangular channels along the side weir for subcritical flow regime. Flow Meas Instrum 46:170-178

Azimi H, Shabanlou S (2016) Comparison of subcritical and supercritical flow patterns within triangular channels along the side weir. Int J Nonlinear Sci Numer Simul 17(7-8):361-368

Azimi H, Shabanlou S (2018) U-shaped channels along the side weir for subcritical and supercritical flow regimes. ISH J Hydraul Eng 138:1-11

Azimi H, Shabanlou S (2019) The effect of froude number on flow field of U-shaped channel along a side weir in supercritical flow regime. Comput Math Model 30(3):254-266

Azimi H, Shabanlou S, Salimi MS (2014) Free surface and velocity field in a circular channel along side weir. Flow Meas Instrum $38: 108-115$ 
Azimi H, Hadad H, Shokati Z, Salimi MS (2015) Discharge and flow field of the circular channel along the side weir. Can J Civ Eng 42:273-280

Azimi H, Bonakdari H, Ebtehaj I (2017a) Sensitivity analysis of the factors affecting the discharge capacity of side weirs in trapezoidal channels using extreme learning machines. Flow Meas Instrum $54: 216-223$

Azimi H, Bonakdari H, Ebtehaj I (2017b) A highly efficient gene expression programming model for predicting the discharge coefficient in a side weir along a trapezoidal canal. Irrig Drain 66(4):655-666

Azimi H, Bonakdari H, Ebtehaj I (2019) Design of radial basis function-based support vector regression in predicting the discharge coefficient of a side weir in a trapezoidal channel. Appl Water Sci 9(4):78

Bagheri S, Heidarpour M (2012) Characteristics of flow over rectangular sharp-crested side weirs. J Irrig Drain Eng 138:541-547

Borghei SM, Jalili MR, Ghodsian M (1999) Discharge coefficient for sharp crested side-weirs in subcritical flow. J Hydraul Eng 125:1051-1056

Cheong H (1991) Discharge coefficient of lateral diversion from trapezoidal channel. J Irrig Drain Eng 117:461-475

El-Khashab AMM (1975) Hydraulics of flow over side weirs. Ph.D. thesis, University of Southampton, England

Emiroglu ME, Kaya N, Agaccioglu H (2010) Discharge capacity of labyrinth side weir located on a straight channel. J Irrig Drain Eng 136:37-46

Emiroglu ME, Agaccioglu H, Kaya N (2011) Discharging capacity of rectangular side weirs in straight open channels. Flow Meas Instrum 22:319-330

Mahmodinia S, Javan M, Eghbalzadeh A (2012) The effects of the upstream froude number on the free surface flow over the side weirs. Procedia Eng 28:644-647

Novak G, Kozelj D, Steinman F, Bajcar T (2013) Study of flow at side weir in narrow flume using visualization techniques. Flow Meas Instrum 29:45-51
Oliveto G, Biggiero V, Fiorentino M (2001) Hydraulic features of supercritical flow along prismatic side weirs. J Hydraul Res 39:73-82

Ramamurthy AS, Zhu W, Vo D (1995) Rectangular lateral weirs in circular open channels. J Hydrol Eng 121:608-612

Uyumaz A (1992) Side weir in triangular channel. J Irrig Drain Eng 118:965-970

Uyumaz A (1997) Side weir in U-shaped channels. J Irrig Drain Eng 123:639-646

Uyumaz A, Muslu Y (1985) Flow over side weirs in circular channels. J Hydraul Eng 111:144-160

Vatankhah AR (2012a) Analytical solution for water surface profile along a side weir in a triangular channel. Flow Meas Instrum 23:76-79

Vatankhah AR (2012b) Water surface profile over side weir in a trapezoidal channel. Proc Inst Civ Eng (ICE) Water Manag 165:247-252

Vatankhah AR (2012c) Water surface profiles along a rectangular side weir in a U-shaped channel (analytical findings). J Hydrol Eng 18:595-602

Vatankhah AR (2012d) New solution method for water surface profile along a side weir in a circular channel. J Irrig Drain Eng 138:948-954

Vatankhah AR (2013) Water surface profile along a side weir in a parabolic channel. Flow Meas Instrum 32:90-95

Venutelli M (2008) Method of solution of non-uniform flow with the presence of rectangular side weir. J Irrig Drain Eng 134:840-846

Yüksel E (2004) Effect of specific energy variation on lateral overflows. Flow Meas Instrum 15:259-269

Publisher's Note Springer Nature remains neutral with regard to jurisdictional claims in published maps and institutional affiliations. 